\title{
Research of Magnetron Phased Array with Mutual Injection Locking for Space Solar Power Satellite/Station
}

\author{
Naoki Shinohara Member (Kyoto University) \\ Hiroshi Matsumoto Non-member (Kyoto University)
}

Keywords: SPS, magnetron, phased array, injection locking

The SPS (Space Solar Power Satellite/Station) will be clean baseload power station in space, which will the hugest space system. For the SPS, we need high efficient, huge, high accurate, light weight and inexpensive phased array in order to transmit energy from SPS in space to ground.

We have proposed and developed a phase controlled magnetron (PCM) with injection locking and PLL (Phase Locked Loop) technique for the high efficient, light weight and inexpensive phased array. The PLL is a control system that generates a signal that has a fixed relation to the phase of a "reference" signal. The PLL circuit responds to both the frequency and the phase of the input signals, automatically raising or lowering the frequency of a controlled oscillator until it is matched to the reference in both frequency and phase.

It has still weak points; (1) it contains approximately $10 \%$ power loss at circulator used for injection locking, (2) we need phase shifter in each PCMs for the phased array. In order to solve the weak points, we propose a magnetron phased array with mutual injection locking. For the magnetron phased array, we only use two PCMs with phase shifters and the other components are self-oscillated and mutual injection locked magnetrons (Fig. 1).

In this paper, we propose new formula for the magnetron phased array with mutual injection locking as follows;

$$
\begin{aligned}
\frac{d \phi}{d t}= & \Delta \omega+\frac{\omega_{i} \rho_{i}}{Q_{e x t}} \sin \left(\psi_{i}-\phi_{i}\right) \\
& +\frac{\varepsilon_{i, j-1} \omega_{i}}{Q_{e x t}} \sin \left(\phi_{i-1}-\phi_{i}\right)+\frac{\varepsilon_{i, j+1} \omega_{i}}{Q_{e x t}} \sin \left(\phi_{i+1}-\phi_{i}\right) \\
& +\frac{\varepsilon_{i, j-2} \omega_{i}}{Q_{e x t}} \sin \left(\phi_{i-2}-\phi_{i}\right)+\frac{\varepsilon_{i, j+2} \omega_{i}}{Q_{e x t}} \sin \left(\phi_{i+2}-\phi_{i}\right) \\
& (i=1,2, \cdots N) \ldots \ldots \ldots \ldots \ldots \ldots \ldots \ldots \ldots \ldots \ldots \ldots \ldots \ldots \ldots \ldots \ldots \ldots
\end{aligned}
$$

Where $\Delta \omega$ is frequency defference between the oscillator and extra injection signal. $\omega_{i}, \varphi_{i}$ are self-oscillation frequency and phase of eachoscillators, respectively. $\varepsilon_{i j}$ is collection factor and

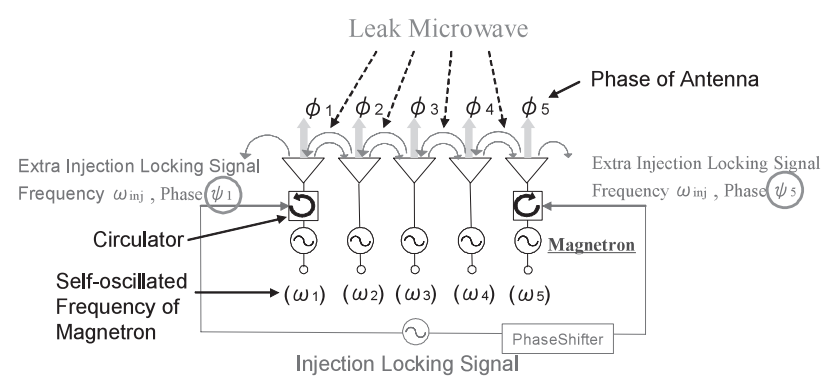

Fig. 1. Proposed magnetron phased array with mutual injection locking $\rho_{i j}=\sqrt{P_{i n j, i} / P_{i}}(i=1, N)$ where $\mathrm{P}_{i n j, i}$ is power of extra injection locking signal and $P_{i}$ is power of oscillator. $\psi_{i}$ is phase of extra injection locking signal. This formula indicates mutual injection locking of phase controlled magnetron and it contains mutual coupling from next and two from next.

We also show experimental results of beam direction control with the magnetron phased array with mutual injection locking. Experimental setup is shown in Fig. 2. We can explain the experimental results with the foumula (1). The experimantal results and theoretical results are good agreement (Fig. 3).

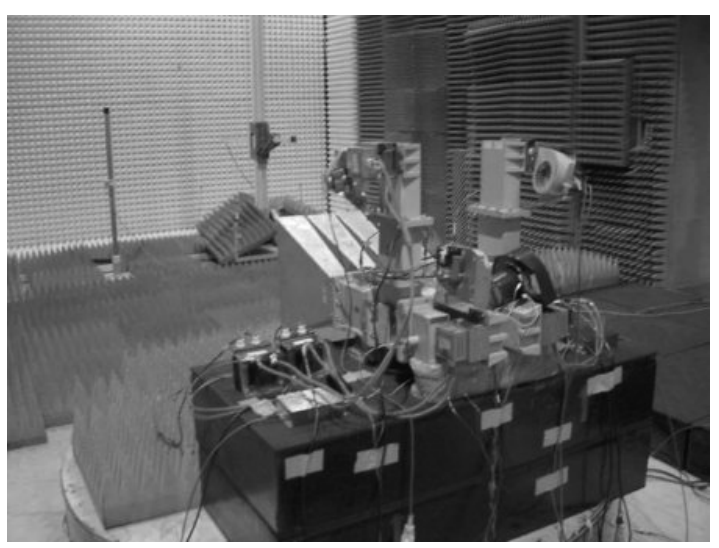

Fig. 2. Experimental setup

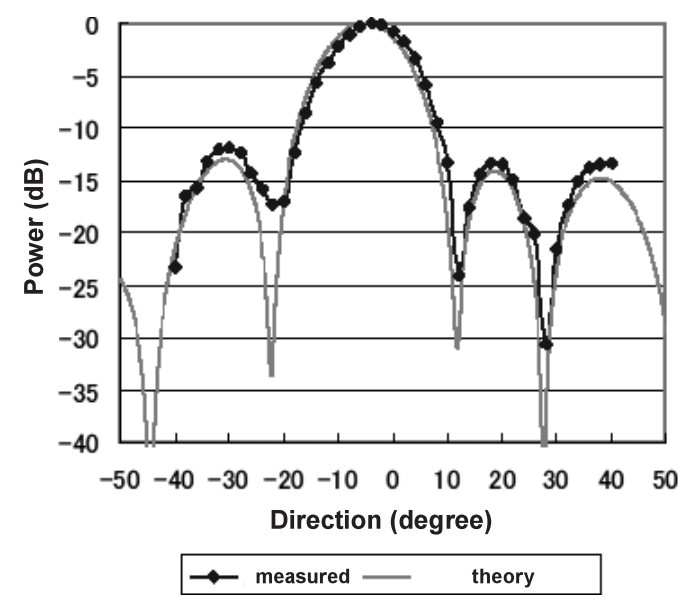

Fig. 3. Beam pattern when phase diffewrence of both ends of magnetrons is $90^{\circ}$. Theoretical pattern is calculatted with Eq. (1) 


\title{
宇宙太陽発電所 SPS のための相互間注入同期法を用いた マグネトロン・フェーズドアレーの研究
}

\author{
正 員 篠原 真毅* 非会員 松本 紘**
Research of Magnetron Phased Array with Mutual Injection Locking for Space Solar Power Satellite/Station \\ Naoki Shinohara*, Member, Hiroshi Matsumoto**, Non-member
}

\begin{abstract}
The SPS (Space Solar Power Satellite/Station) will be clean base-load power station in space. It will be hugest space system and we need high efficient, huge, high accurate, light weight and inexpensive phased array for the SPS in order to transmit energy generated in space from space to ground. We have proposed and developed a phase controlled magnetron (PCM) with injection locking and PLL technique for the high efficient, light weight and inexpensive phased array. It has still weak points; (1) it contains approximately 10\% power loss at circulator for injection locking, (2) we need phase shifter in each PCMs for the phased array. In order to solve the weak points, we propose a magnetron phased array with mutual injection locking. For the magnetron phased array, we only use two PCMs with phase shifters and the other components are self-oscillated and mutual injection locked magnetrons. In this paper, we propose new formula for the magnetron phased array with mutual injection locking. We also show experimental results of beam direction control with the magnetron phased array with mutual injection locking.
\end{abstract}

キーワード : 宇宙太陽発電，マグネトロン，フェーズドアレー，注入同期

Keywords: SPS, magnetron, phased array, injection locking

\section{1. はじめに一宇宙太陽発電所 SPS とは一}

宇宙太陽発電所 SPS (Space Solar Power Satellite/Station) とは, 地球の歳差運動のために 1 年を通じてほとんど地球 の影に入らない静止衛星軌道 $(36,000 \mathrm{~km}$ 上空）に巨大な 太陽電池衛星を建設し, そこで発電した電力をマイクロ波 (=1-10 GHz 程度の電磁波) もしくはレーザー光を用いて 地上に無線電力伝送し，地上でその電力を活用しようとい う構想である。地球の半径約 $6,000 \mathrm{~km}$ に対し, SPS が配置 される $36,000 \mathrm{~km}$ 上空の関係は, Fig. 1 左下にあるように なり (図は夏と冬の位置の例)，1 年のほとんどで SPS は 地球の影に入らないのである。特にマイクロ波を用いた無 線電力伝送は電離層での反射・散乱や大気・雨での吸収・ 散乱がほとんどない「電波の空」と呼ばれる周波数帯を用 いているために量りや雨でも太陽光発電の電力を利用でき

\footnotetext{
*京都大学生存圈研究所

干 611-0011 宇治市五ヶ庄

Research Institute for Sustainable Humanosphere, Kyoto University

Gokasho, Uji 611-0011

** 京都大学

干 606-8501 京都市左京区吉田本町

Kyoto University

Yoshida Hon-machi, Sakyo-ku, Kyoto 606-8501
}

るという利点を持つ。経済性の観点から SPS は地上で 100 万 $\mathrm{kW}$ 以上を利用できる設計がほとんどである。 SPS は夜 昼・天候に無関係でかつ温室効果ガスをほとんど放出しな い(1) という原子力発電と並ぶ将来の基幹電源となる可能性 がある発電所である。1960 年代のマイクロ波無線電力伝送 の研究 ${ }^{(2)}$ に触発され, 1968 年にSPS がはじめて提唱 ${ }^{(3)} さ$ れて以降，1970 年代にはアメリカで ${ }^{(4)}, 1990$ 年代以降は 日本 (5) (7) を中心とした世界中 ${ }^{(8)(9)}$ で様々な SPS の検討が行 われ, 要素技術研究が続いている。SPS はエネルギー源を

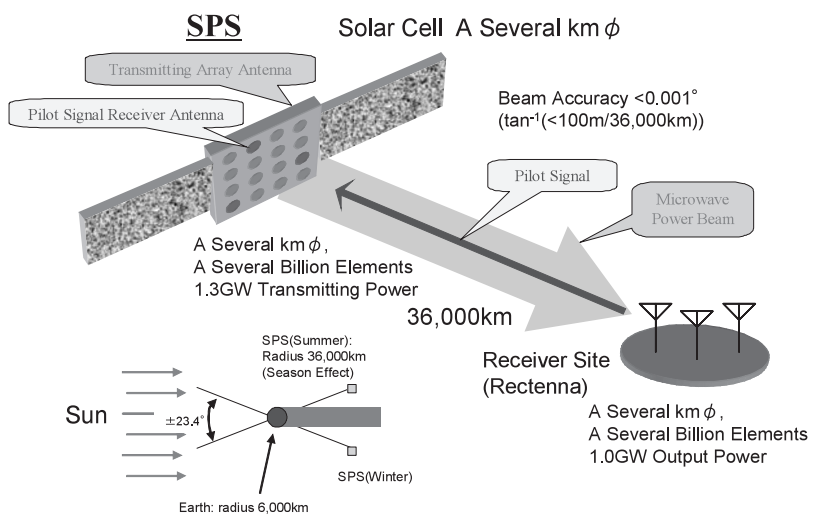

Fig. 1. Concept of SPS. 


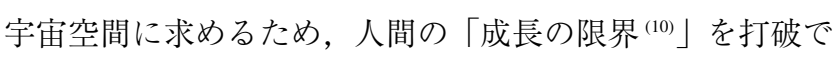
きる可能性がありつつも ${ }^{(1)}$, 同時に発電所としてのコスト も, 将来の技術進歩を見込めば現在の発電方式と変わらな いという試算があり ${ }^{(12)}$ ，現在から未来をつなぐ将来の発電 所として期待が高い。

SPS は温暖化ガスを放出しない基幹電源とできる利点を 生かし，かつ経済性をあげるために，約 100 万 $\mathrm{kW}$ の電力 を無線で約 $36,000 \mathrm{~km}$ 伝送するシステムとなっている。そ のために, 太陽電池の大きさ数 $\mathrm{km}$ 四方, マイクロ波エネル ギーの送電アンテナ, 受電アンテナ共に数 $\mathrm{km}$ の大きさを必 要とし，それでありながら重量 8-9 千トン程度に抑える必 要があると試算されている。Fig. 1 は SPS の概略イメージ 図である。太陽電池技術，宇宙プラズマ中での 100 万 $\mathrm{kW}$ の集配電技術，超大規模宇宙構造物の建設 ·保守 · 運用技 術，ロケット技術等，多岐にわたる研究課題を一つ一つク リアーすべく, 様々な研究が現在も行われている。本研究 で着目したのはSPS 実現に必須課題である超大型アレーア ンテナによるマイクロ波無線電力伝送技術である。本研究 では超大型アレーアンテナの中でも SPS に必須であるが現 在は高コスト体質であるフェーズドアレー技術の容易・安 価な構成法を提案し，その実証実験を行った結果を示す。

\section{2. マイクロ波無線電力伝送への要求}

マイクロ波無線電力伝送ではマイクロ波自体をエネルギー 輸送媒体（=キャリア）とするため，通信やレーダーと異 なり何らかの情報をキャリアに印加（変調やパルス）する 必要がなく，無変調連続波，ピュア・スペクトルで十分で あり，周波数帯域も発振器の $\mathrm{Q}$ や位相雑音限界まで狭くす ることができる。また，マイクロ波無線電力伝送での損失 は，電力からマイクロ波への変換の際の損失，アンテナか ら放射されたマイクロ波が広がりを持ち受電アンテナに収 集されないために発生する損失，受電アンテナで収集され たマイクロ波を再び電力に戻す際の損失，の 3 つの大きな 損失を考えなくてはならない。SPS では宇宙で発生した電 力と地上で利用できる電力の比であるマイクロ波無線電力 伝送の効率として 50\%を目指して研究が行われている。こ の効率は上記の 3 つの損失によって決まるため，50\%を実 現するためには上記の 3 つの損失を小さくすることが必須 である。マイクロ波送電の受電側は通常アンテナと整流回 路 (マイクロ波一電力変換回路) が一体となった「レクテナ」 とよばれるシステムが用いられる。送電側はフェーズドア レーアンテナと呼ばれるレーダー等で最近用いられている アンテナが必須である。フェーズドアレーとは複数のアン テナから放射される電波の位相と振幅を制御し，電波合成 することにより所望のビーム形状を形成し，またビーム方 向を制御するものである。そのため，フェーズドアレーは 機械的なアンテナ面制御が不要であり，任意のアンテナ形 状からビーム制御を行うことができることが特徵である。 SPS は衛星であるために，位置や姿勢，アンテナ形状が固 定される保証がなく，ビーム方向を常に受電サイトに向け
て制御をしておかなくてはならないからである。

フェーズドアレーは現在も一部のレーダー等にしか用い られていない ${ }^{(13)(14)}$ 。非常に高コスト体質なアンテナである ことと，位相の高精度制御技術が高いハードルとなってい るからである。SPS ではさらに「高効率」「超巨大」「高精 度」「軽量」「安価」フェーズドアレーが求められる。現在 のフェーズドアレーはすべて半導体増幅器を用いたシステ ムであるが, 本研究ではSPS に向けコストが非常に安く, かつ高効率で出力重量比で軽量であるマグネトロンを用い たフェーズドアレーを提唱し，実験を行った。

\section{3. 位相制御マグネトロンと注入同期法}

マグネトロンは電子レンジに用いられているマイクロ波 発振菅で, 電場と磁場と共振空洞を利用して発振するために 非常に高効率 (70\%以上), 高出力 ( $\mathrm{kW}$ 以上) でありながら 他のマイクロ波機器に比べ数桁安い $(1,000$ 円/1 台 $(1 \mathrm{~kW})$ 程度）という特徴を持つ。しかし, 高出力の発振器である がために位相の制御が困難であり，また Q が低く，雑音が 多いとされていたために電子レンジのような加熱用途と, 一部のパルスレーダーにしか用いられてこなかった。しか し, 我々はマグネトロンの雑音要因は電源の安定度と電子 放出用のフィラメント温度にあることを明らかにし, 自励 発振状態のマグネトロンでも直流安定化電源を用いて駆動 すれば Q が $1 \times 10^{5}$ 以上になることを示した ${ }^{(15)}$ 。同時に円 筒形状であるマグネトロンの構造上発生が不可避な $\mathrm{n}$ 次高 調波を除き，低周波側高周波側共に杂隹音が $-100 \mathrm{dBc}$ 以下に 抑えられることも示された。 $\mathrm{n}$ 次高調波はそれでもすべて $-60 \mathrm{dBc}$ 以下であり，マグネトロンを加熱以外の用途に十分 用いることができることが示された。マグネトロンの雑音 は電子レンジで用いるような半波倍電圧電源やパルスレー ダーで用いるようなパルス電源の立ち上がり時もしくは立 ち下がり時に発生することも実験的に示されており ${ }^{(16)}$, 常 に定格電圧を印加できる直流安定化電源ではスペクトルの $\mathrm{Q}$ が 3 桁以上上昇し, 雑音も $-100 \mathrm{dBc}$ 以下に抑制できる。

このようにマグネトロンはマイクロ波エネルギー伝送に も利用可能であることが示された。しかし, 自励発振のマグ ネトロンはまだ位相制御を行うことができないし, 温度変化 と共に周波数が変化していくという久点も残っている。そ こで我々はマグネトロンの周波数が印加電圧/電流值によっ て変化する現象と, 弱い基準マイクロ波が外部からマグネ トロンに注入されるとマグネトロンの周波数が基準マイク ロ波の周波数にロックされるという現象を利用して，安価 な電子レンジ用マグネトロンをそのまま用いて位相制御可 能なマグネトロン，位相制御マグネトロン（PCM ; Phase Controlled Magnetron）の開発に成功した ${ }^{(17)}$ 。後者の現象 は注入同期法と呼ばれ, Adlerによって (1) 式のように定式 化されており ${ }^{(18)}$, 周波数安定化に寄与する。

$$
\frac{\Delta \omega}{\omega_{0}}=\frac{2}{Q_{e x t}} \sqrt{\frac{P_{i}}{P_{o}}}
$$




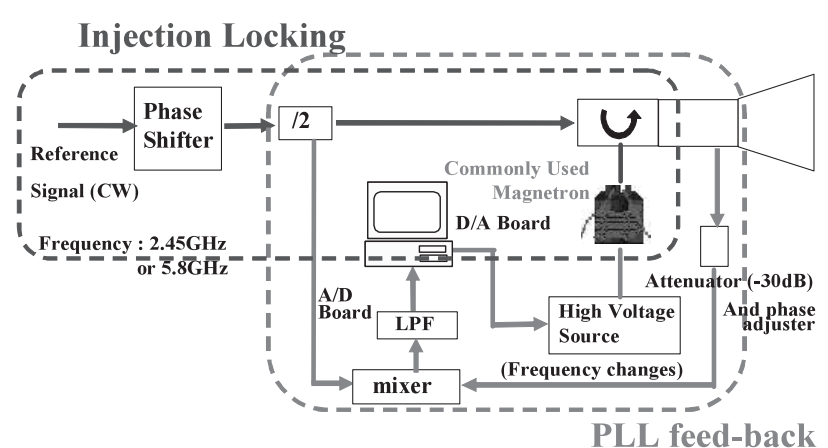

(a) System block diagram

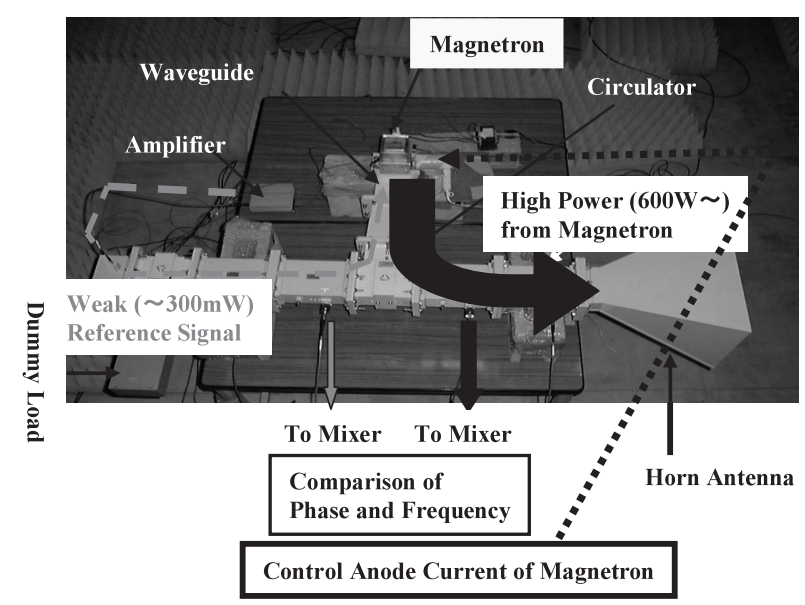

(b) Photo of system

Fig. 2. Phase controlled magnetron ${ }^{(19)}$.

$\omega_{0}$ は発振器（マグネトロン）の自励周波数， $Q_{e x t}$ はマグネ トロンの外部 $\mathrm{Q}$ 值, Po はマグネトロンの振幅, $P i$ は注入信 号の振幅であり， $\Delta \omega$ は注入同期可能な周波数幅，つまり， マグネトロンと注入信号の周波数差が $\Delta \omega$ 以内であればマ グネトロンの周波数は注入信号の周波数にロックされると いうことである。周波数は (1) 式でロックされるが，位相 は以下の式で示すような挙動を示し， $\Delta \omega$ に比例して位相 差が残る。

$$
\frac{d \phi}{d t}=\Delta \omega+\frac{\omega_{0}}{Q_{e x t}} \sqrt{\frac{P_{i}}{P_{o}}} \sin (\psi-\phi)
$$

$\phi, \psi$ はそれぞれマグネトロンと注入信号の位相である。注 入同期は半導体でも同様の現象が発生する。前者の現象を 利用すればマグネトロン+電源を VCO (Voltage Controlled Oscillator）とみなすことができるため, 位相を制御するため の PLL（Phase Locked Loop）制御を行い，位相を安定化/制 御することができるようになる。Fig. 2 は位相制御マグネト

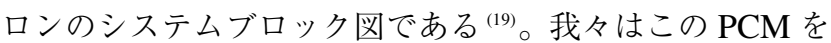
複数用いて実際にマイクロ波送電用フェーズドアレーを構築 し, ビーム制御実験にも成功している ${ }^{(19)}$ 。実験は $2.45 \mathrm{GHz}$ と $5.8 \mathrm{GHz}$ 無変調連続波 $(\mathrm{CW})$ の両システムで行ってい る。位相安定度も $1^{\circ}$ 以下と非常に安定しており，フェーズ ドアレーに用いるには十分な性能である。さらに振幅も同 時に制御可能とした位相振幅制御マグネトロンの開発にも 成功している ${ }^{(20)}$ 。
PCM は安価高効率高出力で位相制御可能ではあるが, SPS のためにはより安価に，より高効率にする必要がある。PCM は注入同期のために導波管サーキュレータを用いており， 10\%程度のマイクロ波損失と共に重量増を招いている。ま た，フェーズドアレーを構築した際，1台の PCM 毎に移相 器が 1 台必要となる。そこで我々は半導体を用いたフェー ズドアレーで時々用いられているフェーズドアレーを構成 する素子間の漏れマイクロ波を用いた注入同期法をマグネ トロンフェーズドアレーに応用することを提案する。

\section{4. 相互結合を利用した位相制御マグネトロン フェーズドアレー}

〈4・1〉基礎理論＼cjkstart半導体を用いたフェーズドアレー では, 隣同士のアンテナの相互結合による漏れマイクロ波, もしくは直接的にライン等で結合させたマイクロ波を注入 信号として半導体発振器に注入同期法を用い，周波数安定 とビーム制御を行う (21)(22)。この場合，素子同士の結合によ り, 以下に示す Adlerの式によりそれぞれの発振器の位相 が一意に決定される(21)。

$$
\begin{aligned}
\frac{d \phi_{i}}{d t}= & \Delta \omega+\frac{\varepsilon_{i, j-1} \omega_{i}}{Q_{e x t}} \sin \left(\phi_{i-1}-\phi_{i}\right) \\
& +\frac{\varepsilon_{i, j+1} \omega_{i}}{Q_{e x t}} \sin \left(\phi_{i+1}-\phi_{i}\right) \quad(i=1,2, \cdots N)
\end{aligned}
$$

(3) 式は $\mathrm{N}$ 個の発振器の素子間結合を用いた注入同期現 象を表す連立方程式であり， $\omega_{i} ， \phi_{i}$ はそれぞれ各発振器の 自励周波数及び位相, $\varepsilon_{i j}$ は $i$ 番目と $j$ 番目の素子間の結合 強度を表している。素子間の結合強度 $\varepsilon_{i j}$ は, 発振器 $j$ から 発振器 $i$ の方向への信号の電力を $P_{i j}$, 発振器 $i$ の出力電力 を $P_{i}$ とすると以下のように表すことができる。

$$
\varepsilon_{i j}=\sqrt{\frac{P_{i j}}{P_{i}}} \ldots \ldots \ldots \ldots \ldots \ldots \ldots \ldots \ldots \ldots \ldots \ldots
$$

また (3) 式で，両端の発振器については隣が1つしかない ので，添字が 0 あるいは $N+1$ となる項は無視する。(3) 式 で結合強度 $\varepsilon_{i j}$ の值がすべて等しいと仮定すると, 各発振 器の自励周波数を以下のように設定することにより, 各発 振器の位相を両端の発振器間位相差を等分割した形にする ことができる。つまり，

$$
\phi_{i}-\phi_{i-1}=\Delta \phi(\text { 一定值 })
$$

が (3) 式の解の 1 つとなりうる。(5) 式を (3) 式に代入し定 常状態 $\left(d \phi_{i} / d t=0\right)$ を考えることにより, 各発振器の自励 周波数についての以下の必要条件が出てくる。

$$
\omega_{i}= \begin{cases}\omega_{0}+\Delta \omega & (i=1) \\ \omega_{0} & (1<i<N) \\ \omega_{0}-\Delta \omega & (i=N)\end{cases}
$$

ここで $\omega_{0}$ は目標とする出力周波数, $\Delta \omega=\varepsilon \omega_{0} / Q_{e x t} \cdot \sin \Delta \phi$ である。すなわち両端の発振器の自励周波数を, 目標とす 


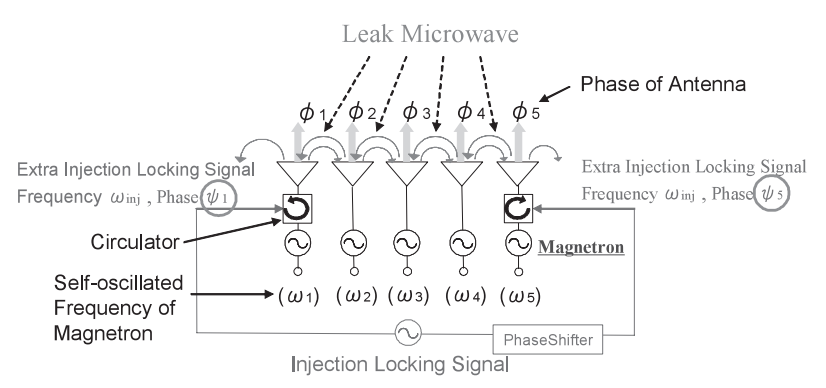

Fig. 3. Concept of phased array of PCMs with mutual injection locking.

る出力周波数に対して，お互いに反対方向に $\Delta \omega$ だけずら すことにより，各発振器の位相が両端の発振器間位相差を 等分割した形にすることができる。ある $\Delta \omega$ の值に対して, $\Delta \phi$ の值が 2 つ存在するが, 実際は発振器間位相差 $\Delta \phi$ のと りうる範囲が $-90^{\circ}<\Delta \phi<+90^{\circ}$ に限られる。したがって $\Delta \omega$ を決めると $\Delta \phi$ が 1 つに決まり, ビームの方向制御が可 能となる。つまり，両端の発振器の周波数さえ制御してや れば移相器不要でビーム制御が可能となる。つまり，マグ ネトロンフェーズドアレーの場合，両端に位相制御マグネ トロンを用い，その他は自励発振のマグネトロンを用いる だけで相互結合によりビーム方向が制御できるということ になる。その場合のマグネトロンフェーズドアレー構成の 例を Fig. 3 に示す。

〈4·2〉 マグネトロンへの応用しかし, マグネトロン の自励発振はそのままだと温度特性等により安定度が悪い ことは先に述べた。電子レンジ用マグネトロンの自励発振 周波数の時間変化の例を Fig. 4 に示す。変動幅は約 $6 \times 10^{-5}$ 程度と小さいものの，この変動の元で相互結合による注入 同期がかかるか，検証してみなければならない。また，基 本方程式は (3) 式を用いるが，Fig. 3 にあるように $i=1, N$ 番目のマグネトロンには (2) 式で決まる直接の注入同期法 を用いているため，相互結合を用いたマグネトロンフェー ズドアレーの場合，(2) 式と (3) 式を組み合わせた以下の新 しい式を用いることになる。

$$
\begin{aligned}
\frac{d \phi}{d t}= & \Delta \omega+\frac{\omega_{i} \rho_{i}}{Q_{e x t}} \sin \left(\psi_{i}-\phi_{i}\right) \\
& +\frac{\varepsilon_{i, j-1} \omega_{i}}{Q_{e x t}} \sin \left(\phi_{i-1}-\phi_{i}\right)+\frac{\varepsilon_{i, j+1} \omega_{i}}{Q_{e x t}} \sin \left(\phi_{i+1}-\phi_{i}\right) \\
& (i=1,2, \cdots N) \ldots \ldots \ldots \ldots \ldots \ldots \ldots \ldots \ldots \ldots \ldots \ldots \ldots \ldots \ldots \ldots
\end{aligned}
$$

ここで $\rho_{i}$ は，両端のマグネトロンからの放射マイクロ波の 振幅に対する外部注入信号の振幅で，放射マイクロ波の電 力を $P_{i}$, 外部注入信号の電力を $P_{\mathrm{inj}, \mathrm{i}}$ とすると, 次式で表 される。

$$
\rho_{i j}=\sqrt{\frac{P_{i n j, i}}{P_{i}}} \quad(i=1, N)
$$

また $\psi_{i}$ は両端の外部注入同期信号の位相である。 $\rho_{i}$ と $\psi_{i}$

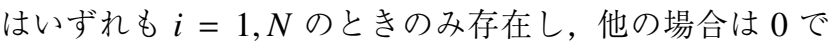
ある。

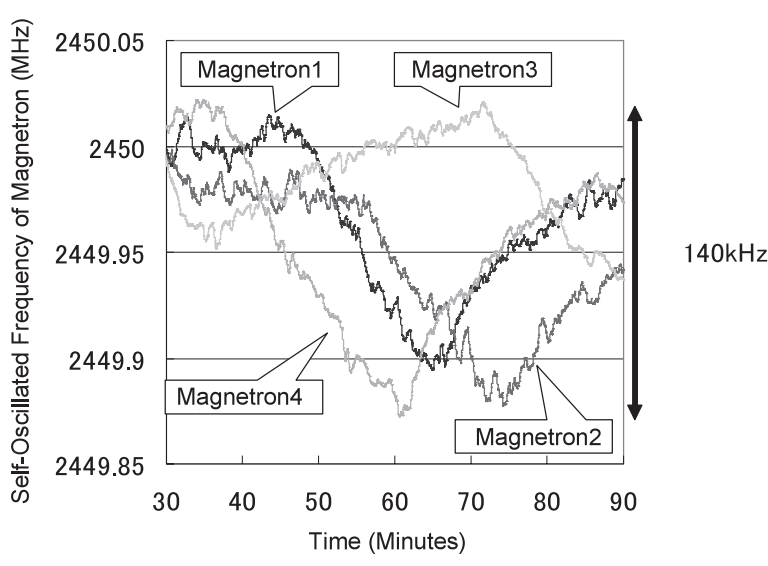

Fig. 4. Time dependence of self-oscillated frequency of cooker-type magnetrons.

(7) 式で結合強度 $\varepsilon_{i j}$ 及び注入信号強度 $\rho_{i}$ の值がすべて等 しいと仮定する。このとき，前節と同様，(5) 式を (7) 式に 代入し定常状態 $(d \phi i / d t=0)$ を考えることにより, 各アン テナの位相が両端のアンテナ間位相差を等分割した形にな るための，各マグネトロンの自励周波数の条件が出てくる。

$$
\omega_{i}= \begin{cases}\omega_{\text {int }}+\Delta \omega_{1} & (i=1) \\ \omega_{\text {int }} & (1<i<N) \\ \omega_{\text {int }}-\Delta \omega_{N} & (i=N)\end{cases}
$$

ここで

$$
\Delta \omega_{i}=\frac{\varepsilon \omega_{i}}{Q_{e x t}}\left[\sin \Delta \phi-\sin \left(\phi_{i}-\psi_{i}\right)\right] \quad(i=1, N)
$$

ある $\Delta \omega_{i}$ の值に対して, $\Delta \phi$ の值が 2 つ存在するが，実際は アンテナ間位相差 $\Delta \phi$ のとりうる範囲は $-90^{\circ}<\Delta \phi<+90^{\circ}$ に限られる。さらにすべてのマグネトロンの自励周波数が 外部注入同期信号の周波数に一致したとする。すなわち

$$
\omega_{i}=\omega_{i n j} \text { for all } i \text {. }
$$

となったとする。このとき $\phi_{1}-\psi_{1}=\Delta \phi, \phi_{N}-\psi_{N}=\Delta \phi$ となるので結局,

$$
\psi_{N}-\psi_{1}=(N+1) \Delta \phi
$$

が得られる。すなわち，すべてのマグネトロンの自励周波 数が，両端の外部注入同期信号の周波数と一致すると，外 部注入信号間の位相差が等分割され各アンテナに割り当て ることができる。 $\left|\psi_{N}-\psi_{1}\right|<180^{\circ}$ であれば， $\Delta \phi$ は 1 つに 決まる。 $\left|\psi_{N}-\psi_{1}\right|>180^{\circ}$ の場合については次節で触れる。 さて，このシステムにおいても，マグネトロンの自励周波 数の不安定性が出力の位相の安定度, ビームの方向制御の 安定度に影響を与える可能性のあることは容易に想像でき る。ただし，前節のシステムと異なるのは，マグネトロン の自走周波数が摇らいでも周波数ロック範囲内であれば, 各出力の周波数は外部注入信号の周波数に同期していると いう点である。 


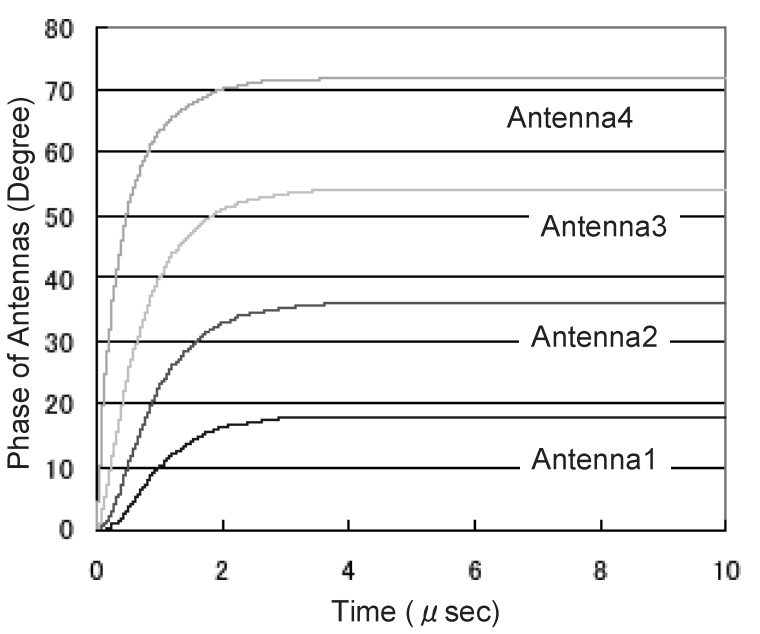

Fig. 5. Transit response on ideal condition.

〈4·3〉 シミュレーション（7) 式でモデル化される システムの基本的な性質を調べるため, 単純なシミュレー ションをいくつか行う。本節では断りがない限りすべての シミュレーションに打いて, アンテナ数 $N=4$, マグネト ロンの外部 $Q$ 值 $Q_{\mathrm{ext}}=174$, 両端の外部注入信号間位相差 $\psi_{4}-\psi_{1}=90^{\circ}$ としておく。N=4 はSPS で用いるような 何十億素子に比べれば極めて少ないアンテナ数であるが, 実験的な制約と，外部注入同期の基礎物理を理解するため に用いたものである。外部 $Q$ 值はマグネトロンの実験值か ら設定している。まず，理想的な状態について調べる。本 システムでは, 隣接するアンテナ間の結合強度 $\varepsilon_{i j}$ がすべ て等しく，また外部注入信号の強度 $\rho$ とも等しいことが仮 定されている。ここで，すべてのマグネトロンの自走周波 数 $\omega_{i}$ が, 両端の外部注入同期信号の周波数 $\omega_{\text {inj }}$ と一致する と，外部注入信号間の位相差が等分割されるということで あった。これは解析的にも簡単に導くことができたが，過 渡応答を含めて示す。 $\varepsilon=\rho=\sqrt{1[\mathrm{~W}] / 500[\mathrm{~W}]}=0.0447$, $\omega_{i}=\omega_{\mathrm{inj}}=2.45[\mathrm{GHz}]$ とした場合のシミュレーションの結 果をFig. 5 に示す。Fig. 5 より約 $4 \mu$ 穴定常状態に落ち着 き，各位相が等分割されていることがわかる。

次にマグネトロンで問題が発生する可能性がある自励周 波数の摇らぎの条件下での相互間注入同期に関したシミュ レーション結果を示す。Fig. 4 に示した自励周波数の変動 データを用いたシミュレーションを行う。マグネトロンの 放射電力も実データを用いる。他のパラメータについても 他のシミュレーションと同様，マグネトロンの外部 $\mathrm{Q}$ 值 $Q_{\mathrm{ext}}=174$, 外部注入信号の周波数 $\omega_{i n j}=2.45 \mathrm{GHz}$, 外部 注入信号電力 $P_{i n j}=1 \mathrm{~W}$ と設定する。隣接するアンテナに 漏れるマイクロ波の電力を放射電力の $-33 \mathrm{~dB}$ とする。

両端の外部注入信号間位相差 $\psi_{N}-\psi_{1}=90^{\circ}$ とし, Fig. 4 の 1 時間分の測定データを用いてシミュレーションした結 果を Fig. 6 および Fig. 7 に示す。Fig. 6 は各出力の位相の 時間変化を示している。一方, Fig. 7 は Fig. 6 の位相の結 果の中から 1 分ごとのデー夕を取り出し，それぞれビーム

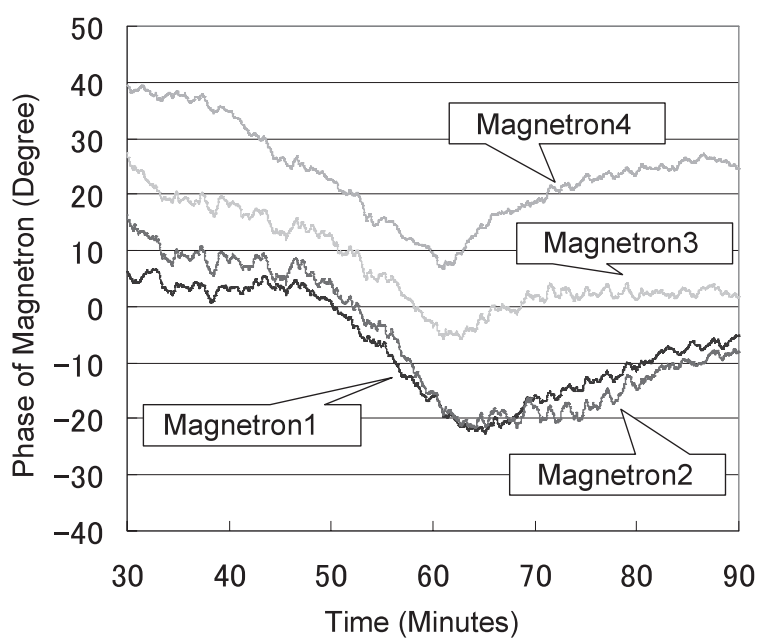

Fig. 6. Time dependence of phase of magnetrons.

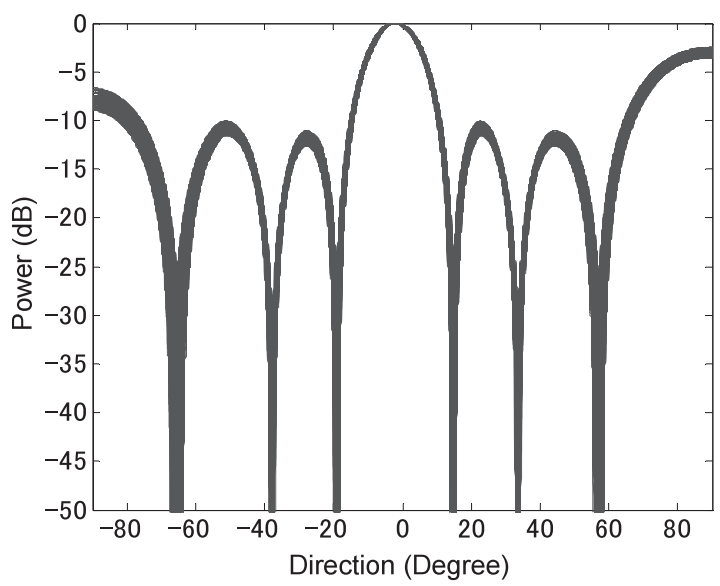

Fig. 7. Time dependence of beam pattern (only array factor).

パターンを計算したものを重ね合わせたものである。Fig. 6 のように，各マグネトロンの自励周波数が時間的に変動す るに伴い出力の位相も大きく変化しているが，この変化が 各アンテナ間で無相関ではなく, すべての位相が連動して 変化しているため, Fig.7 のようにメインビームの方向は時 間変化せず，サイドローブについてもほぼ変化しないとい える。このことから，本システムはマグネトロンのように 自励周波数が不安定な発振器を用いてもフェーズドアレー のビーム方向制御が可能であり，また逆にビーム制御に非 常に適しているといえる。

$\langle\mathbf{4} \cdot \mathbf{4}\rangle$ 実 験 前節で示したシミュレーション結果 の検証のために実際の相互注入同期を用いたマグネトロン フェーズドアレーの実験を行った。実験はシミュレーショ ンと同様 Fig. 4 のデー夕を取得した 4 台のマグネトロン を用い，アンテナには Fig. 8 に示すホーンアンテナを用い た。周波数は $2.45 \mathrm{GHz} て ゙ ， 4$ 素子を物理限界の $0.86 \lambda$ (約 $10.5 \mathrm{~cm})$ 間隔に配置した 1 次元アレーを用いて実験を行っ た (Fig. 9)。

実験システムの構成図を Fig. 10 に，実験の様子を Fig. 11 に示す。Fig. 9 の 1 次元 4 素子ホーンアンテナアレーの両 


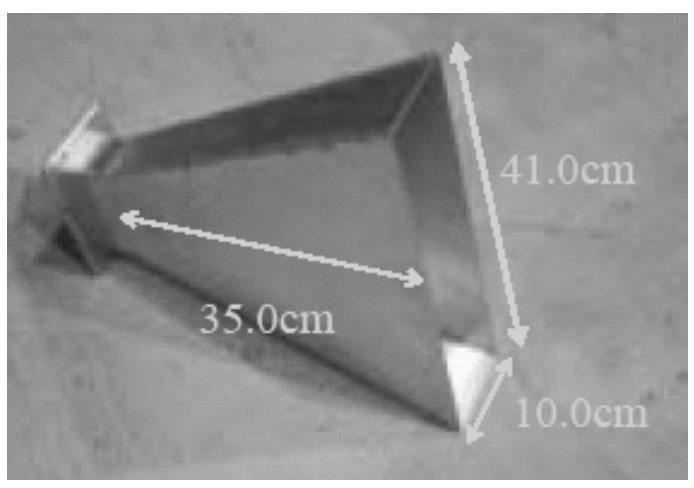

Fig. 8. Horn antenna for experiment.

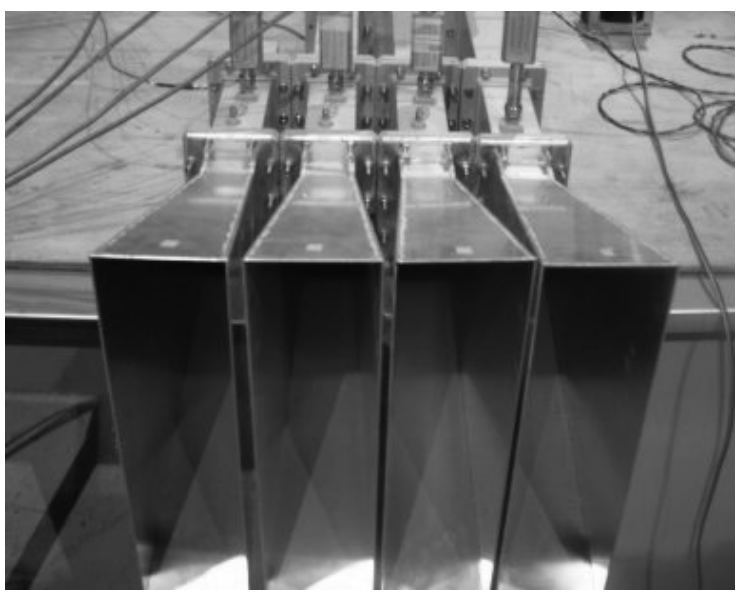

Fig. 9. 1-D array for experiment.

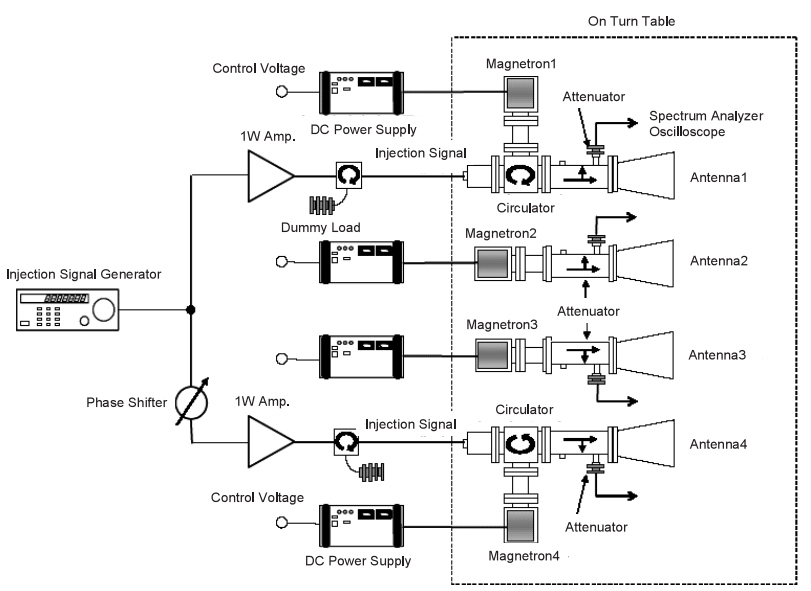

Fig. 10. Experimental setup.

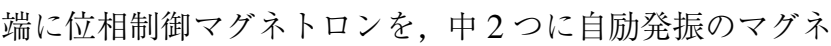
トロンをそれぞれ接続し, 電波暗室内で回転台にシステム 一式を乗せ，ビームパターンを測定した。

このアレーでの結合係数の実測を行った結果が Table 1 である。この※の結果を用いて (2) 式から結合係数を求め ることが出来る。実験值と理論值の比較のため，(7)式を用 いた理論検討に必要なその他のパラメータも Table 2 に示 すように実測している。

Fig. 12 は正面方向のフェーズドアレーのビームパターン である。シミュレーションは，4つのホーンアンテナそれ

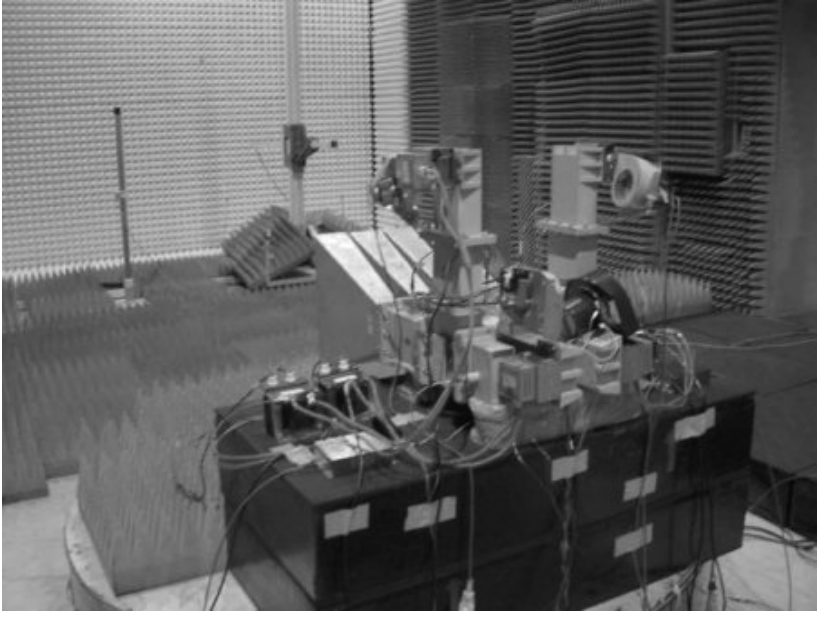

Fig. 11. Photo of experiment.

Table 1. Measurement of leak microwave power.

\begin{tabular}{|c|c|c|}
\hline & $\begin{array}{c}\text { Leak Power } \\
(\mathrm{mW})\end{array}$ & $\begin{array}{c}\text { Leak Power } / \\
\text { Radiated Power }(\mathrm{dB})\end{array}$ \\
\hline From 1 Next $※$ & 300 & -33 \\
\hline From 2 Next & 120 & -37 \\
\hline From 3 Next & 34 & -44 \\
\hline From 4 Next & 41 & -43 \\
\hline From 5 Next & 2 & -56 \\
\hline
\end{tabular}

Table 2. Experimental parameters of magnetron phased array.

\begin{tabular}{|l|c|}
\hline $\begin{array}{l}\text { Frequency of External Injection } \\
\text { Locking Signal }\end{array}$ & $2.45 \mathrm{GHz}$ \\
\hline $\begin{array}{l}\text { Frequency of Self-Oscillated } \\
\text { Frequency }\end{array}$ & 2.45 for all i \\
\hline $\begin{array}{l}\text { Power of External Injection } \\
\text { Locking Signal }\end{array}$ & $1 \mathrm{~W}$ \\
\hline $\begin{array}{l}\text { Radiated Power from Magnetron } \\
(\mathrm{i}=1 \text { ) }\end{array}$ & $590 \mathrm{~W}$ \\
\hline $\begin{array}{l}\text { Radiated Power from Magnetron } \\
(\mathrm{i}=2)\end{array}$ & $490 \mathrm{~W}$ \\
\hline $\begin{array}{l}\text { Radiated Power from Magnetron } \\
\text { (i=3) }\end{array}$ & $405 \mathrm{~W}$ \\
\hline $\begin{array}{l}\text { Radiated Power from Magnetron } \\
\text { (i=4) }\end{array}$ & $440 \mathrm{~W}$ \\
\hline $\begin{array}{l}\text { Ratio between Leak Power / } \\
\text { Radiated Power }\end{array}$ & $-33 \mathrm{~dB}$ \\
\hline External Q of Magnetron & 174 \\
\hline
\end{tabular}

ぞれのビームパターンの実測值を用いてビーム合成した結 果であり，よく一致していることが分かる。

続いて両端のアンテナの位相差を $30^{\circ}, 90^{\circ}, 150^{\circ}$ とし た場合のビーム制御実験結果と, Table 2 のパラメータと (7) 式を用いたシミュレーション結果を元に各アンテナの 


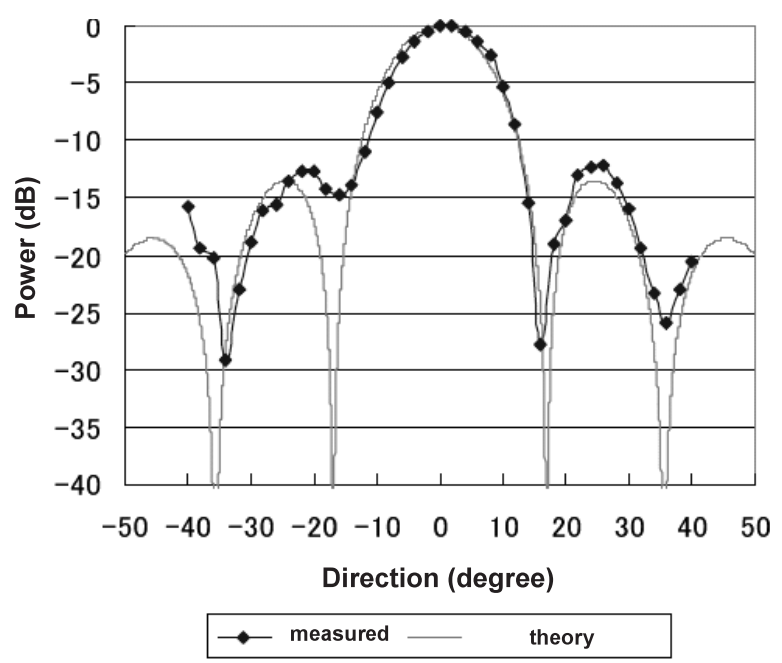

Fig. 12. Beam pattern $\left(0^{\circ}\right.$, front $)$.

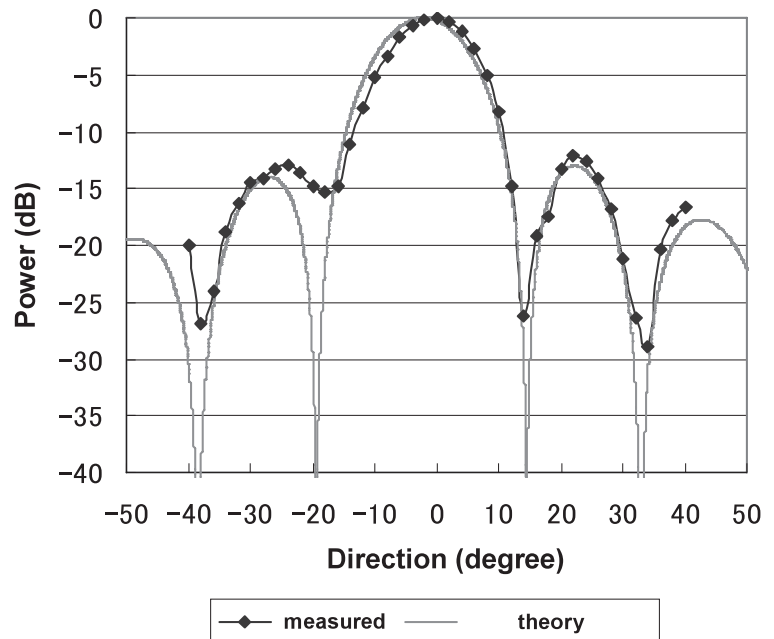

Fig. 13. Beam pattern $\left(30^{\circ}\right.$ phase deference of edge antennas).

パターン実測值から計算したビームパターン理論值の結果 を Fig. 13〜 Fig. 15 に示す。その他の位相差を与えた場合の 主ビームの角度の実験值と理論值の比較を Table 3 に示す。 これから明らかなように，両端の位相差が小さいうちは理 論と実験が比較的一致しているが，両端の位相差を大きく していくと徐々に実験值と理論值が離れていくことが分か る。各アンテナの位相差を詳しく調べてみると, 理論では 等分されるはずの位相差が, 実験では内側 2 つのアンテナ の位相差が接近していることが判明した。(7) 式から得られ る位相と実験值との比較を Fig. 16 に示すが, 理論值と実験 值があまりあっていない。

$\langle\mathbf{4} \cdot 5\rangle$ 改良理論と実験両端の位相差を大きくして いくと徐々に実験值と理論值が離れていく原因は Table 1 に示す 2 つ隣からの漏れ電力が予想よりも大きく，この漏 れ電力でも注入同期がかかってしまったためではないかと 仮定した。(7) 式は隣からの漏れ電力による注入同期しか力 バーしていないため, さらに $2 つ$ 隣からの漏れ電力による 注入同期もカバーする以下の新しい理論式を導入する。

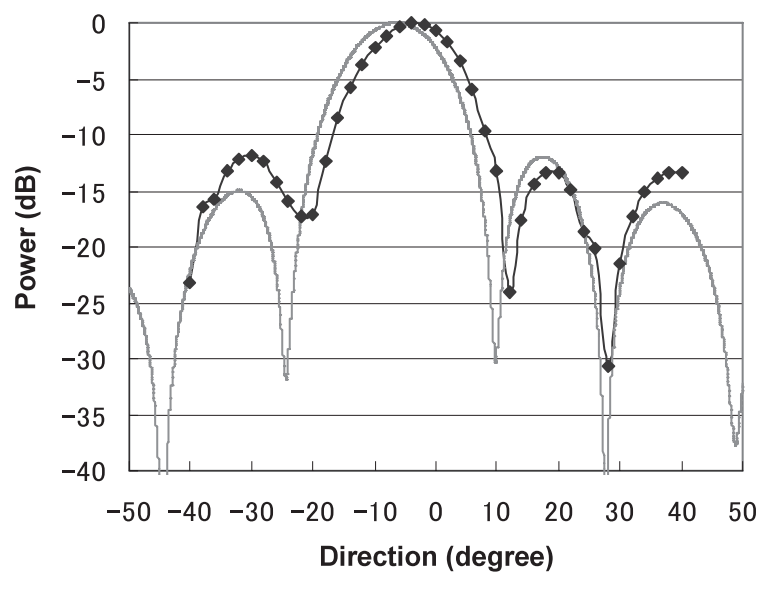

$\multimap$ measured $\longrightarrow \quad$ theory

Fig. 14. Beam pattern $\left(90^{\circ}\right.$ phase deference of edge antennas).

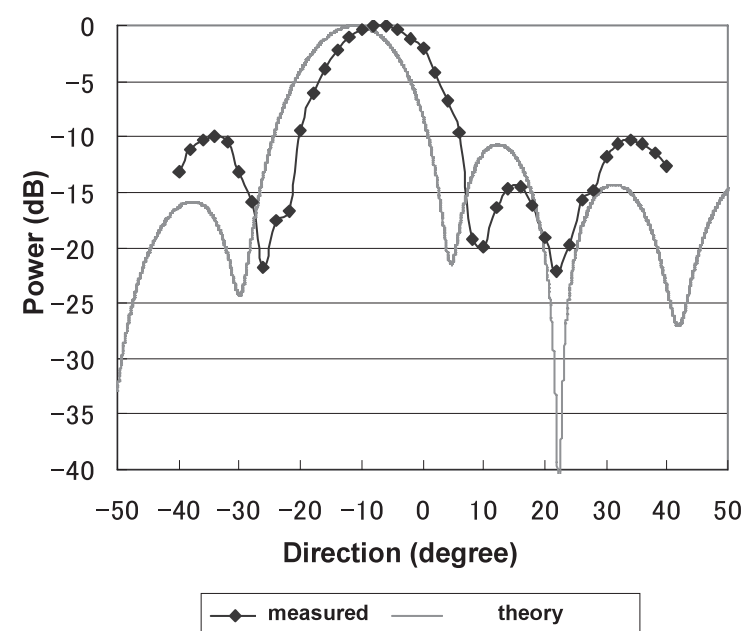

Fig. 15. Beam pattern $\left(150^{\circ}\right.$ phase deference of edge antennas).

Table 3. Direction of main beam (measured and theory).

\begin{tabular}{|r|r|r|r|}
\hline $\begin{array}{l}\text { Phase Difference } \\
\text { of Edge Antennas } \\
\left({ }^{\circ}\right)\end{array}$ & $\begin{array}{l}\text { Direction } \\
\text { Main } \begin{array}{r}\text { of } \\
\text { Beam }\end{array}\left(^{\circ}\right)\end{array}$ & $\begin{array}{l}\text { Direction of } \\
\text { Main Beam } \\
\left(\text { Theory) }\left({ }^{\circ}\right)\right.\end{array}$ & $\begin{array}{l}\text { Error } \\
\left({ }^{\circ}\right)\end{array}$ \\
\hline-150 & +8 & +11.2 & -3.2 \\
\hline-120 & +6 & +8.75 & -2.75 \\
\hline-90 & +6 & +6.46 & -0.46 \\
\hline-60 & +4 & +4.26 & -0.26 \\
\hline-30 & +2 & +2.13 & -0.13 \\
\hline 0 & +2 & 0 & -2 \\
\hline+30 & 0 & -2.13 & +2.13 \\
\hline+60 & -2 & -4.26 & +2.26 \\
\hline+90 & -4 & -6.46 & +2.46 \\
\hline+120 & -6 & -8.75 & +2.75 \\
\hline+150 & -6 & -11.2 & +5.2 \\
\hline
\end{tabular}




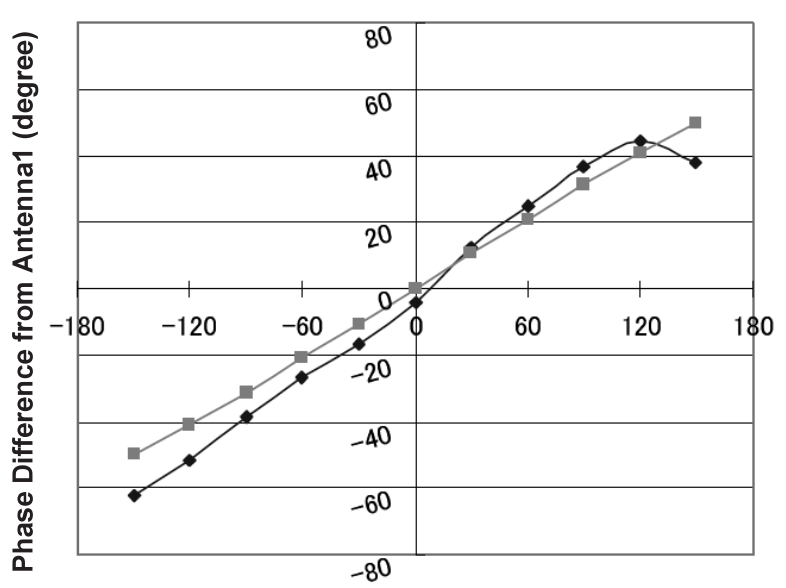

Phase Difference of Edge Antennas (degree)

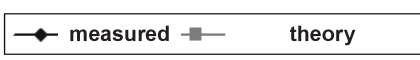

(a) Antenna 2

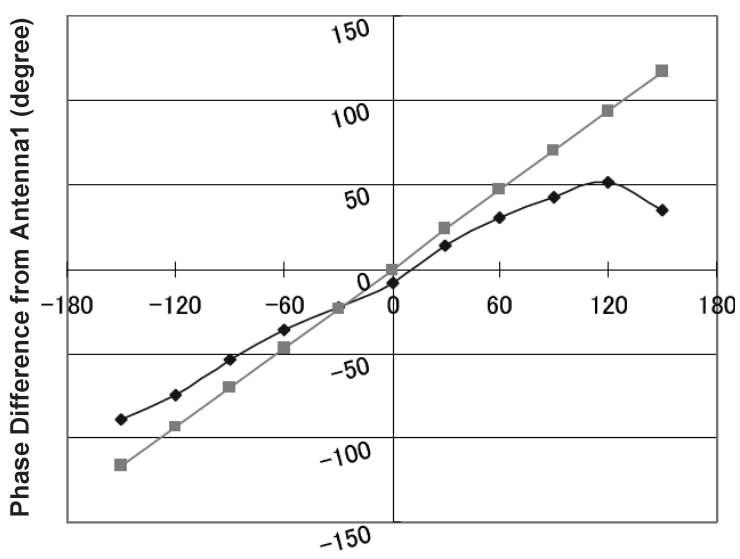

Phase Difference of Edge Antennas (degree)

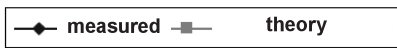

(b) Antenna 3

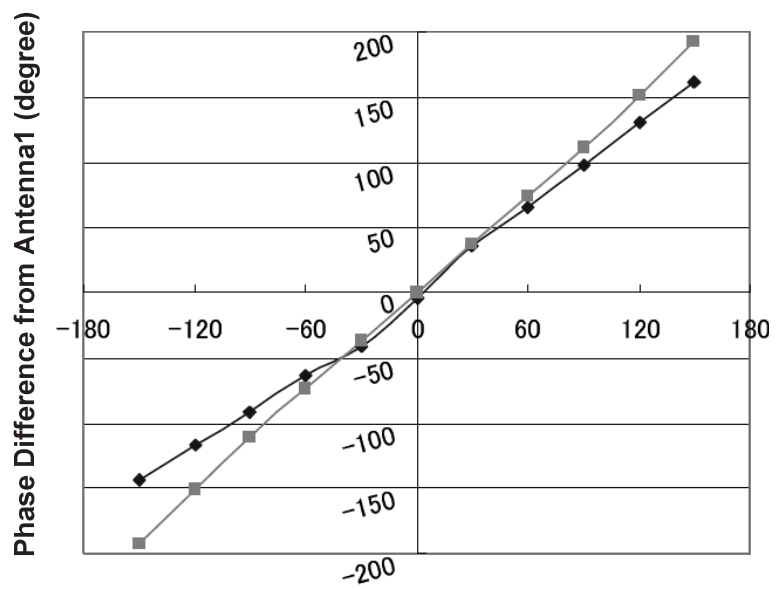

Phase Difference of Edge Antennas (degree)

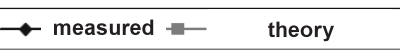

(c) Anttena 4

Fig. 16. Phase difference between antenna (vs. antenna 1) (measured and theory).

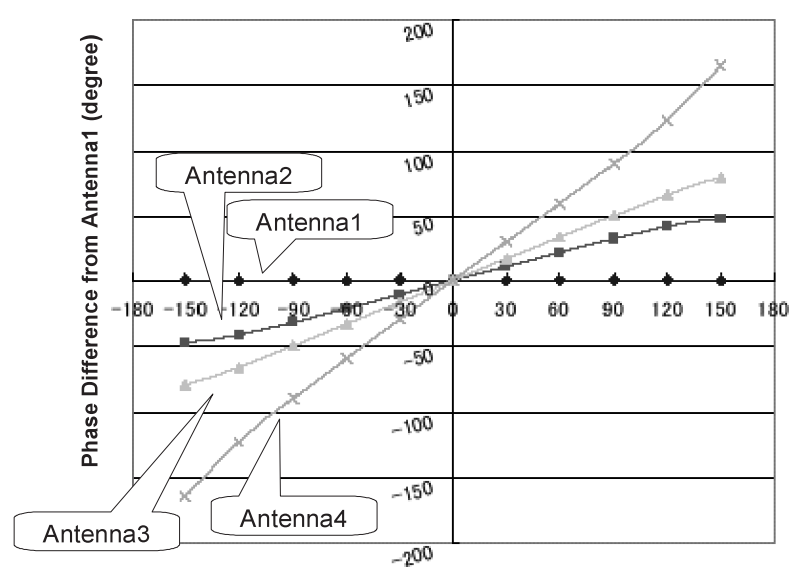

Phase Difference of Edge Antennas (degree)

Fig. 17. Simulation results of phase difference of each antennas (by Eq. (13)).

Table 4. Direction of main beam (measured and theory by Eq. (13)).

\begin{tabular}{|c|c|c|c|}
\hline $\begin{array}{l}\text { Phase Difference } \\
\text { of Edge Antennas } \\
\text { ( ) }\end{array}$ & $\begin{array}{l}\text { Direction of } \\
\text { Main Beam } \\
\text { (Measured) }\left({ }^{\circ}\right)\end{array}$ & $\begin{array}{l}\text { Direction of Main } \\
\text { Beam (Theory by } \\
\text { Equation(13)) ( ) }\end{array}$ & $\begin{array}{l}\text { Error } \\
\left({ }^{\circ}\right)\end{array}$ \\
\hline-150 & +8 & +9.12 & -1.12 \\
\hline-120 & +6 & +6.81 & -0.81 \\
\hline-90 & +6 & $\begin{array}{r}+4.99 \\
\end{array}$ & -1.01 \\
\hline-60 & +4 & $\begin{array}{r}+3.27 \\
\end{array}$ & -0.73 \\
\hline-30 & +2 & +1.63 & -0.37 \\
\hline 0 & +2 & 0 & -2 \\
\hline+30 & 0 & -1.63 & +1.63 \\
\hline+60 & -2 & -3.27 & $\begin{array}{r}+1.27 \\
\end{array}$ \\
\hline+90 & -4 & -4.99 & +0.99 \\
\hline $\begin{array}{r}+120 \\
\end{array}$ & -6 & -6.81 & +0.81 \\
\hline $\begin{array}{r}+150 \\
\end{array}$ & -6 & -9.12 & +3.12 \\
\hline
\end{tabular}

$$
\begin{aligned}
\frac{d \phi}{d t}= & \Delta \omega+\frac{\omega_{i} \rho_{i}}{Q_{e x t}} \sin \left(\psi_{i}-\phi_{i}\right) \\
& +\frac{\varepsilon_{i, j-1} \omega_{i}}{Q_{e x t}} \sin \left(\phi_{i-1}-\phi_{i}\right)+\frac{\varepsilon_{i, j+1} \omega_{i}}{Q_{e x t}} \sin \left(\phi_{i+1}-\phi_{i}\right) \\
& +\frac{\varepsilon_{i, j-2} \omega_{i}}{Q_{e x t}} \sin \left(\phi_{i-2}-\phi_{i}\right)+\frac{\varepsilon_{i, j+2} \omega_{i}}{Q_{e x t}} \sin \left(\phi_{i+2}-\phi_{i}\right) \\
& (i=1,2, \cdots N) \ldots \ldots \ldots \ldots \ldots \ldots \ldots \ldots \ldots
\end{aligned}
$$

(13) 式を用いてシミュレーションをしなおし, 測定結 果との比較を行うこととする。アンテナ間結合強度 $\varepsilon$ は Table 2 より, 隣のアンテナには $-33 \mathrm{~dB}, 2$ つ隣のアンテナ には $-37 \mathrm{~dB}$ 漏れこむとして計算した結果を用いる。まず 目標の両端アンテナ間位相差に対する各アンテナの位相を シミュレーションした結果を Fig. 17 に示す。予想通り，2 つ隣のアンテナとの結合を考慮すると位相は等分割されず, 内側の 2 つのアンテナの位相が近くなるという結果となっ た。次に，アンテナ 1 の位相を基準とした場合の他のアン テナの位相を, 測定值とシミュレーションとで比較したも のを Fig. 18 に示す。これらの図を Fig. 16 と比べると, 測 


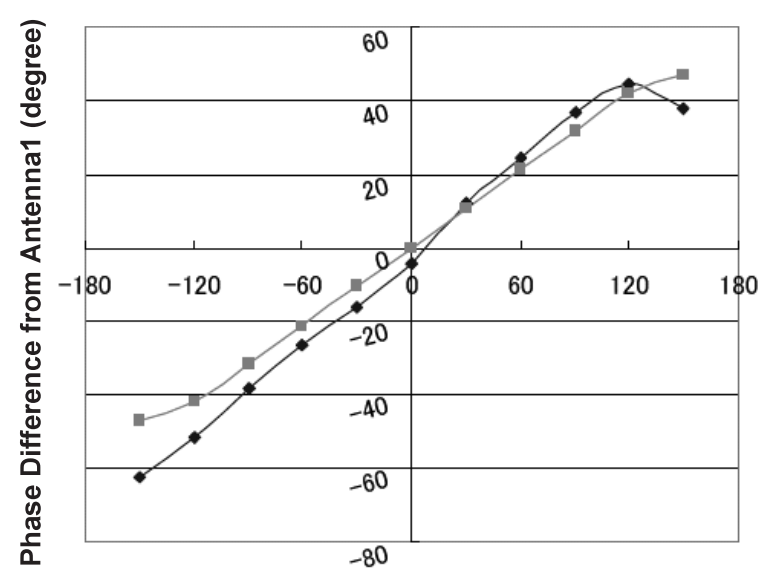

Phase Difference of Edge Antennas (degree)

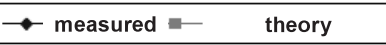

(a) Antenna 2

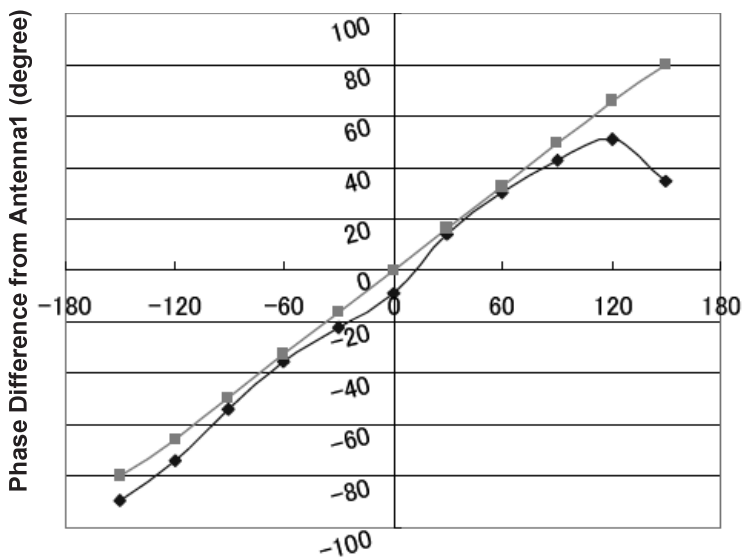

Phase Difference of Edge Antennas (degree)

$\rightarrow$ measured $=$ theory

(b) Antenna 3

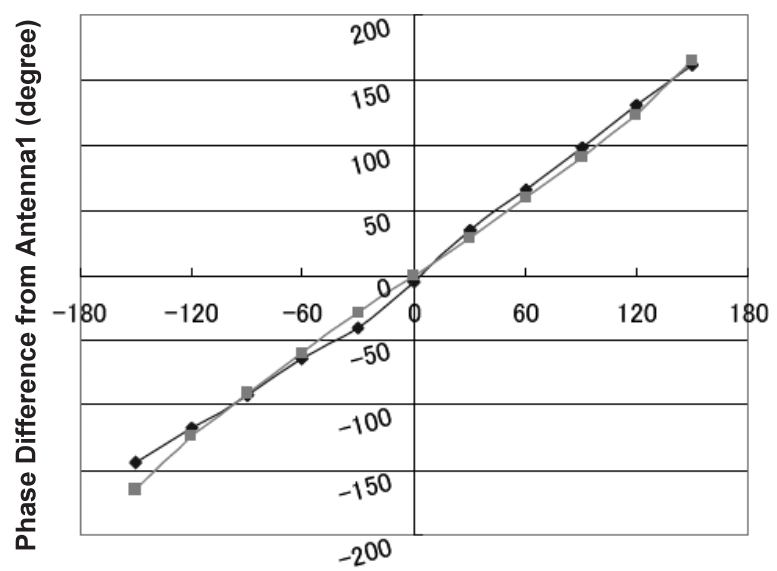

Phase Difference of Edge Antennas (degree)

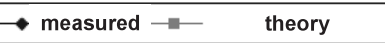

(c) Anttena 4

Fig. 18. Phase difference between antenna (vs. antenna 1) (measured and theory by Eq. (13)).

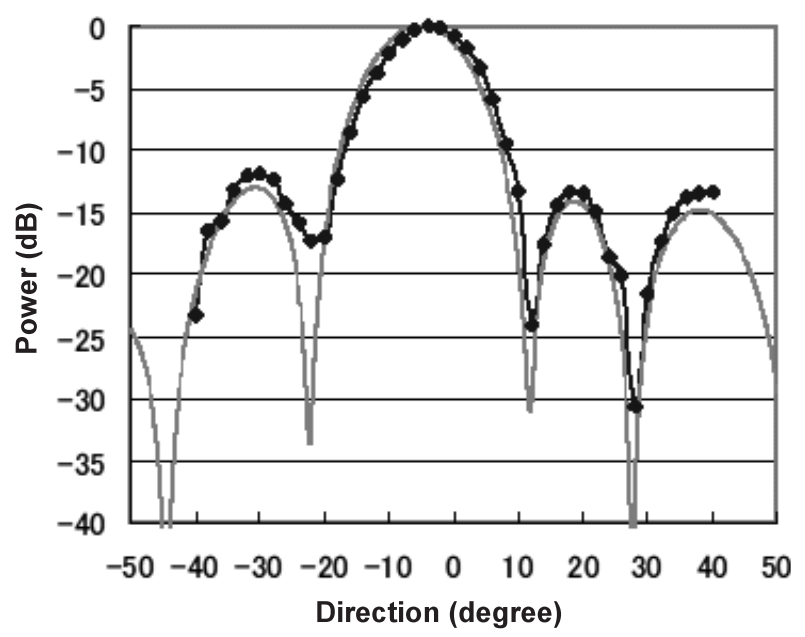

$\longrightarrow$ measured $\longrightarrow$ theory

Fig. 19. Beam pattern $\left(90^{\circ}\right.$ phase deference of edge antennas) (theory by Eq. (13)).

定值とシミュレーションとの位相の一致の程度が高くなっ ていることがわかる。

(13) 式を用いて理論值を計算し直し, 実験と比較した表 が Table 4 であり, ビームパターンの一例として両端のアン テナ位相差を $90^{\circ}$ とした場合の結果を Fig. 19 に示す。(7) 式を用いた理論值よりもよく一致していることが分かる。

5. まとめ

本論文ではこれまで半導体発振器アレーでしか用いられ なかった相互結合による注入同期法を利用したフェーズド アレー技術を初めてマグネトロンフェーズドアレーに適用 した結果を示した。位相制御マグネトロンを両端にのみ配 置してフェーズドアレーをより安価に構築できる方法を提 案し，実際にビーム制御にも成功した。また，Adlerの理論 式を位相制御マグネトロンアレーに拡張し，また 2 つ隣の 漏れ波まで考慮した理論式を提唱して，より実験結果に近 い理論值を計算した。本論文で示した理論と実験はSPS で 用いるような何十億素子に比べれば極めて基礎的な実験に 過ぎない。しかし,「両端のみの移相器で中の自励発振を制 御する」結果を SPS に応用する際には, 「数個に 1 つ移相 器を持ち, その相互作用でその他の励発振を制御する」こ とで対応できると考えている。その場合，当然相互作用が 多岐にわたりより複雑な挙動を示すことが予想されるため, (13) 式をさらに発展させ, シミュレーションと実証を行う 必要がある。

謝 辞

本研究は本研究室大学院生（当時）の水谷浩之君の協力 で行われたものである。また, 本実験は京都大学生存圈研 究所マイクロ波エネルギー伝送実験装置 METLAB を用い て行われた。

(平成 19 年 11 月 8 日受付，平成 20 年 4 月 30 日再受付) 


\section{文献}

（1）吉岡完治・管 幹雄・野村浩二・朝倉啓一郎：「宇宙太陽発電衛星の $\mathrm{CO}_{2}$ 負荷」, 学振未来 WG2-1, 19 (1998)

(2) W.C. Brown: "The history of power transmission by radio waves", IEEE Trans. MTT, Vol.32, No.9, pp.1230-1242 (1984)

(3) P.E. Glaser: "Power from the Sun; Its Future", Science, No.162, pp.857-886 (1968)

(4) DOE and NASA Report: "Satellite Power System; Concept Development and Evaluation Program", Reference System Report (1979)

(5) H. Matsumoto: "Research on Solar Power Station and Microwave Power Transmission in Japan: Review and Perspectives", IEEE Microwave Magazine, No.12, pp.36-45 (2002)

（6）藤田辰人 · 吉田裕之 ·鈴木拓明 - 木皿且人 - 久田安正 - 森 雅裕 : 「JAXAに㧍ける宇宙エネルギー利用システム (SSPS) 研究の現状」, 信学技報, SPS2007-01 (2007-04), pp.7-10 (2007)

（7） 三原荘一郎・斉藤 孝・小林裕太郎・金井 宏:「SSPS に関する USEF の活動状況 (2006)」, 信学技報, SPS2007-01 (2007-04), pp.1-6 (2007)

(8) J.C. Mankins: "A fresh look at the concept of space solar power", Proc. of $3^{\text {rd }}$ Int. Conf. on Solar Power from Space-SPS' 97 , S7041 (1997)

(9) L. Summerer and F. Ongaro: "Solar Power from Space-Validation of Options for Europe", Proc. of $4^{\text {th }}$ Int. Conf. on Solar Power from SpaceSPS'04, pp.17-26 (2004)

(10) D.H. Meadows, D.L. Meadows, J. Randers, and W.W. Behrens, III; The limits to growth-A report for THE CLUB OF ROME'S project on the predicament of mankind, Universe Books, New York (1972)

(11) Y. Yamagiwa and M. Nagatomo: "An Evaluation Model of Solar Power Satellites Using World Dynamics Simulation", Space Power, Vol.11, No.2, pp.121-131 (1992)

（12）（株）三菱総合研究所：平成 16 年度宇宙航空研究開発機構委託業務 成果報告書「宇宙エネルギー利用システム総合研究」(2005)

(13) E. Brookner: "Phased Arrays and Radars—Past, Present and Future", Microwave Journal, Cover Feature, No.1 (2006)

（14）（財）国際衛星通信協会, 衛星通信研究, No.71, pp.19-43

(15) T. Mitani, N. Shinohara, H. Matsumoto, and K. Hashimoto: "Improvement of Spurious Noises Generated from Magnetrons Driven by DC Power Supply after Turning off Filament Current", IEICE Trans. Electron, Vol.E86-C, No.8, pp.1556-1563 (2003)

（16） 三谷友彦·篠原真毅・松本 紘・相賀正幸·桑原なざさ・半田貴典 : 「電子レンジ用マグネトロンから発生するノイズの時間解析」, 信学 論 C, Vol.J87-C, No.12, pp.1146-1154 (2004)

（17）篠原真毅・三谷友彦・松本 紘:「位相制御型マグネトロンの開発研 究」, 信学論 C, Vol.J84-C, No.3, pp.199-206 (2001)

(18) R. Adler: "A Study of Locking Phenomena in Oscillators", Proc. of I.R.E and Waves and Electrons, Vol.34, pp.351-357 (1946)

(19) N. Shinohara, H. Matsumoto, and K. Hashimoto: "Phase-Controlled Magnetron Development for SPORTS: Space Power Radio Transmission System", The Radio Science Bulletin, No.310, pp.29-35 (2004)

(20) N. Shinohara and H. Matsumoto: "Phased Array Technology with Phase and Amplitude Controlled Magnetron for Microwave Power Transmission",
Proc. of $4^{\text {th }}$ Int. Conf. on Solar Power from Space-SPS'04, pp.117-124 (2004)

(21) R.A. York and T. Itoh: "Injection- and Phase-Locking Techniques for Beam Control", IEEE Trans. MTT, Vol.46, No.11, pp.1920-1929 (1998)

(22) K.D. Stephan and W.A. Morgan: "Analysis of interinjection-locked oscillators for integrated phased arrays", IEEE Trans. AP, Vol.35, pp.771-781 (1987)

篠 原 真 毅 （正員） 1968 生。1991 年京都大学工学部電子工

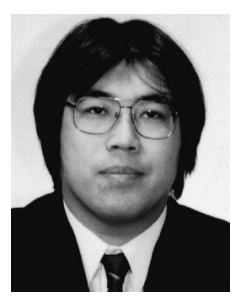
学科卒業。1993 年京都大学大学院工学研究科修 士課程修了。1996 年同大学大学院工学研究科博 士課程修了。同年同大学超高層電波研究センター 助手，2000 年同センターの改組により宙空電波 科学研究センター助手, 2001 年同センター助教 授, 2004 年同センターの改組により生存圈研究所 助 (准) 教授となり, 現在に至る。主として宇宙 太陽発電所とマイクロ波エネルギー伝送に関する研究に従事。工博。 IEEE，URSI，電子情報通信学会会員。

松 本

紘 (非会員) 1942 年生。1965 年京都大学工学部電

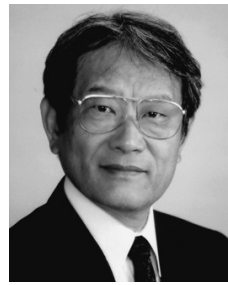
子工学科卒業。1967 年京都大学大学院工学研究科 修士課程修了。1977 年同大学超高層電波研究セン ター教授，1992１998 年まで同センター長。2000 年同センターの改組により宙空電波科学研究セン ター教授, 2002 年同センター長, 2004 年同セン ターの改組により生存圈研究所教授・所長, 2005 年京都大学理事・副学長となり, 現在に至る。京 都大学名誉教授。宇宙航空研究開発機構客員教授。中国武漢大学客座 教授。工博。専門はスペースプラズマ物理学, 宇宙電波工学, 宇宙工 ネルギー伝送。1975 年日本電磁気学会田中館賞, 1993，1998 年 NASA Group Achievement Award, 1998 年アメリカ地球物理学会 (JGR) フエ ロー, 1999 年情報通信月間推進協議会志田林三郎賞, 2002 年 IEEE フェロー, 2004 年英国王立天文学協会 RAS-Associate, 同年近畿情報通 信協議会会長表彰, 2006 年 Russian Federation of Cosmonautics Gagarin Medal，同年科学技術分野の文部科学大臣表彰科学技術賞受賞。地球 電磁気 - 地球惑星圈学会評議員, 元会長。国際電波科学 (URSI) 元会 長。アメリカ地球物理学会会員。 